\title{
8 線式速度勾配測定用プローブの開発と円柱後流測定への応用 Development of eight-sensor hot wire probe for velocity gradients and its application to measurement of cylinder wake.
}

\author{
○学 齋藤良太 (名エ大) 正 牛島達夫（名エ大） \\ 正鈴木博貴 (名エ大) 正 長谷川豊（名エ大）
}

\author{
Ryota SAITO, Nagoya Institute of Technology, Gokiso-cho, Showa-ku, Nagoya-shi, Aichi-ken, 466-8555 \\ Tatsuo USHIJIMA, Nagoya Institute of Technology \\ Hiroki SUZUKI, Nagoya Institute of Technology \\ Yutaka HASEGAWA, Nagoya Institute of Technology
}

\begin{abstract}
We have developed new multi-sensor hot wire probe in order to measure all components of velocity gradient simultaneously. Simultaneous measurement of all components of velocity gradient is important for understanding dynamics of non-linear energy transfer. Our probe uses less sensors ( 8 wires) than the previously proposed 12 -sensor probe so that size of probe can be more compact. The new probe was tested against wake of circular cylinder.
\end{abstract}

Key Words: $\quad$ multi-sensor hot wire probe, velocity gradient, cylinder wake

\section{1. 緒論}

自然界の造形は，しばしば自己相似性を保持するフラクタ ル幾何によって表現される(1). 21 世紀になり，このフラクタ ル形状の物体を通過して生成される乱流の減衰機構が, 従来 の実験室や乱流理論で説明されていたものと異なっている ことが報告されている ${ }^{(2),(3)}$. 一般的に知られている格子乱流 では, 乱流はエネルギーが大きなスケールから小さなスケー ルへ順々に輸送されるカスケードによって減衰が起こる。そ の場合, 乱流エネルギーは格子からの距離のほぼー1 乗に比 例して減衰する．ところが，フラクタル形状を持つ格子から 生成された乱流は, 非常に大きな乱れ速度を示すだけでなく, 乱流エネルギーが指数関数的に減衰する場合がある。

3 次元の乱流では, 渦度べクトルが伸張を絶えず受け続け ることで，スケール間のエネルギー移動が起こっている．渦 度ベクトルが伸張を受けると，粘性の影響がない場合は，伸 張によってその周囲の渦管は角運動量を維持しながら細く なり，これにより，エネルギーは大きなスケールから小さな スケールに移動する。これらの機構を明らかにするには，エ ンストロフィー(渦度の 2 乗)の生成項である $\omega_{i} s_{i j} \omega_{i}\left(\omega_{i}\right.$ は渦度 の $i$ 成分, $s_{i j}$ は変形速度テンソルの $i j$ 成分)を知る必要があり, 速度勾配テンソルの全 9 成分を同時に測定する必要がある. そこでこのような測定を行うために, 本研究では 8 線式の速 度勾配測定用熱線プローブの開発を進めている.

熱線流速計は，点計測であるものの，高い時間分解能で乱 流の変動を計測することができる. 熱線流速計では通常, 速 度の 1 成分 $(\mathrm{I}$ 型)または 2 成分 $(\mathrm{X}$ 型)を測定するが，速度の 3 成分を測定するには，熱線は 3 線または 4 線必要となる。さ らに，速度勾配の全 9 成分を測定するためには，9ないし 12 本の熱線をコルモゴロフ長のオーダの空間に張らなければ ならず，製作が困難であり，世界では 12 線式(4)，9線式(5), 8 線式 $(\mathrm{X} \text { 線式 } 4 \text { 本の組み合わせ })^{(6)}$ など 2,3 の研究グループ が扱うのみである. そこで本研究では 4 組の 3 線式熱線流速 計の隣同士の熱線を共有することで， 8 線で速度勾配テンソ ルを測定できる熱線流速計を製作した(Fig.1). 熱線の数を少 なくすることで，製作が簡単になり，さらにコンパクトに製 作することが可能となり，微小スケールでの乱流のエネル ギ一輸送機構を実験的に明らかにできる．本研究ではこの 8 線式プローブを製作し, 円柱後流の流れを測定し，過去の研 究と比較することで，このプローブの動作を確認することが 目的である。
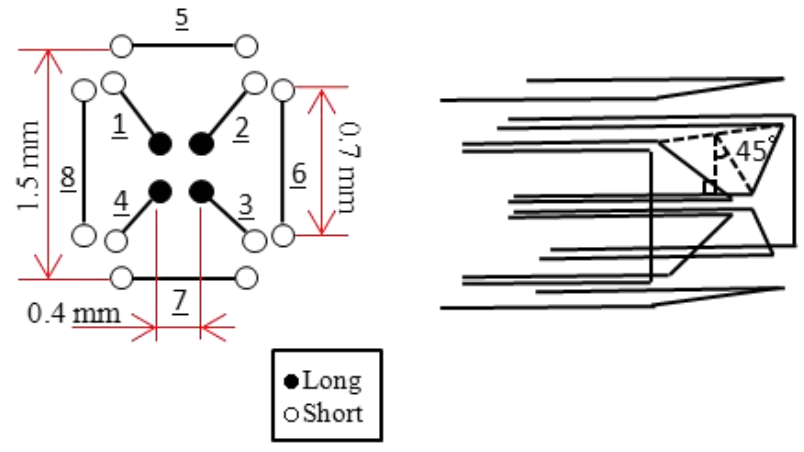

Fig.1 Eight-sensor hot wire probe

\section{2. 実験装置及び実験方法}

実験装置は，一様な流れが確認されている口径が $130 \mathrm{~mm}$ $\times 130 \mathrm{~mm}$ の風洞を用いる。座標系は直交座標系を用い，縮 流部出口の流路中央を原点とし，流れ方向を $x$, スパン方向 を $y$, 高さ方向を $z$ とする. 8 線式プローブの検定は縮流部 出口から $50 \mathrm{~mm}$ 後方において行う. 円柱後流測定では設定流 速 $U_{\infty}=5 \mathrm{~m} / \mathrm{s}$ とし, 縮流部出口に直径 $d=5 \mathrm{~mm}$ の円柱を $y$ 軸に 沿って設置する. 測定点は $x / d=50,100$ の 2 箇所で, 高さ方 向に $2 \mathrm{~mm}$ 刻みにトラバースして測定を行った.

8 線式プローブ(Fig.1)については，プロング間の感知部長 さ $0.7 \mathrm{~mm}$, 熱線には直径 $3.1 \mu \mathrm{m}$ のタングステン線を用いた. プロングは直径 $0.3 \mathrm{~mm}$ のピアノ線の先端を削り, 先端径 $0.05 \mathrm{~mm}$ となったものを使用している。 また， 8 線式プロー ブの中央部は高さが横から見て $45^{\circ}$ (正面から風を流寸場合, 中央部の熱線の迎え角はそれぞれ $\left.54.7^{\circ}\right)$ になるように設計し た. なお, Fig.1 の下線付きの数字はチャンネル数を示して いる.

\section{3. 検定方法}

8 線式プローブの検定は従来の 3 線式プローブと同様の手 順で行う。 8 線式プローブの方向感受性は，プローブの角度 $\varphi$ (回転角) と流れ方向に対する角度 $\psi($ (ヨー角 $)$ の両方で特徴づ けられる. 本研究の検定ではヨー角 $\psi=-5^{\circ}, 0^{\circ}, 5^{\circ}, 10^{\circ}, 15^{\circ}$, $20^{\circ}$ (6 点)においてそれぞれ, 回転角 $\varphi=0^{\circ} \sim 360^{\circ}$ の範囲で $15^{\circ}$ 刻み(24 点)で行う。これらの座標系を Fig.2 に示す。 


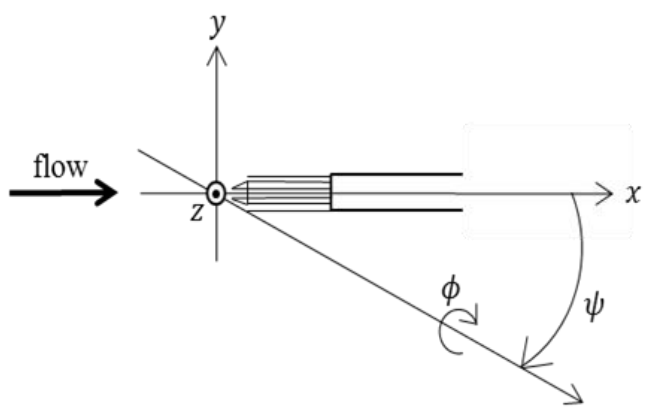

Fig.2 Coordinate system

Fig.3, Fig.4 に設定流速 $U=6 \mathrm{~m} / \mathrm{s}$ の場合の検定結果の一例を 示す. Fig.3 は ch.1，2，5の熱線を $\psi=10^{\circ}$ において 8 線式プ ローブを $\varphi=0^{\circ} \sim 360^{\circ}$ (横軸)に回転させた場合の電圧 $E[\mathrm{~V}]($ 縦 軸)の変化を示寸. Fig.4 は ch.1, 2 の熱線について, $\psi=0^{\circ}, 5^{\circ}$, $10^{\circ}, 15^{\circ}$ において $\varphi=0^{\circ} \sim 360^{\circ}$ に回転させた場合の, ch. 1 の電 圧 $E_{l}[\mathrm{~V}]$ (横軸) と ch.2の電圧 $E_{2}[\mathrm{~V}]($ 縦軸)の変化を示す.なお, 放射線状に広がる黒色の線は回転角 $\varphi$ が同じ点で結んだ。

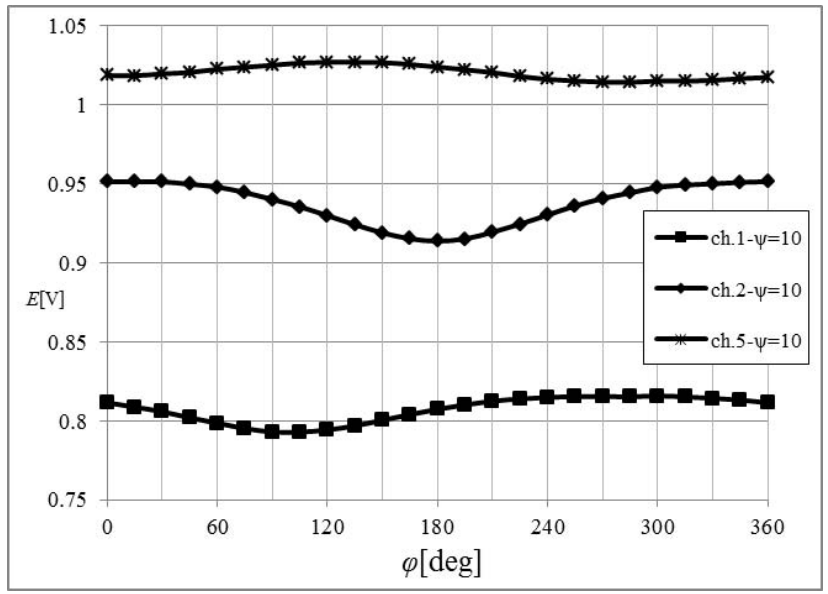

Fig.3 Calibration curve ( $E$ vs. $\varphi)$

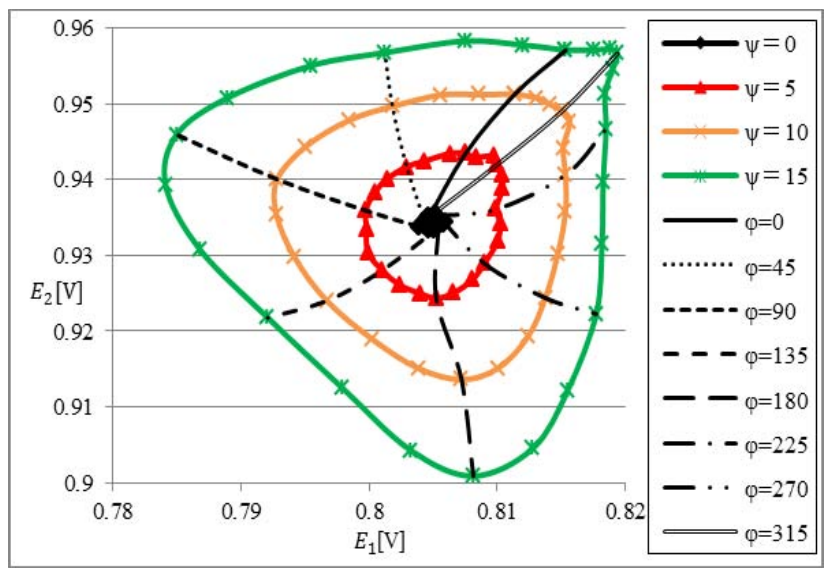

Fig.4 Calibration curve ( $E_{1}$ vs. $\left.E_{2}\right)$

電圧から流速を求めるためにはキングの法則

$$
E^{2}=A \sqrt{U}+B
$$

を用いる.このため上記の検定を流速が異なる場合において 行う必要がある. 本研究では設定流速 $U_{\infty}=5 \mathrm{~m} / \mathrm{s}$ のため, 設定 流速 $U=4,6 \mathrm{~m} / \mathrm{s}$ において検定を行った.

\section{4. 実験結果}

8 線式プローブの ch.5 8 は通常の I 型プローブとして機 能する.この I 型プローブがら得られた円柱後流の流れ方向 ( $x$ 方向)速度分布と乱流強度分布の一例をそれぞれ Fig.5,

Fig.6 に示す.ここで政そその位置での平均流速 $[\mathrm{m} / \mathrm{s}], U_{0}$ は設 定流速 $U_{\infty}$ からの円柱後流中央 $(y=0)$ での速度欠損 $[\mathrm{m} / \mathrm{s}]$ であり, 横軸は半值幅 $L$ で無次元化している.

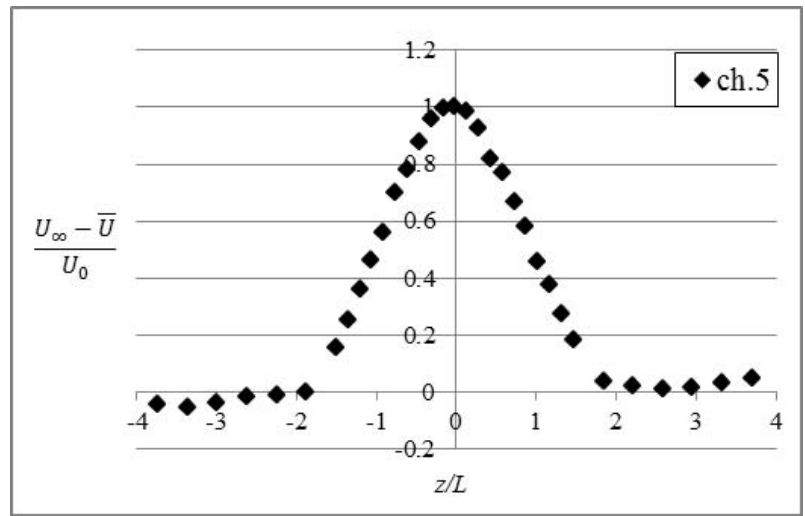

Fig.5 Velocity distribution $\left(U_{\infty}=5 \mathrm{~m} / \mathrm{s}, \quad x / d=50\right)$

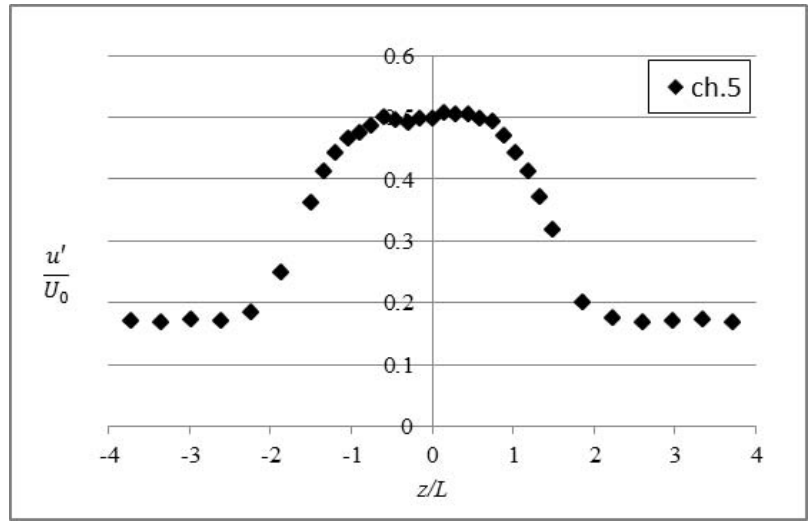

Fig.6 Rms velocity distribution $\left(U_{\infty}=5 \mathrm{~m} / \mathrm{s}, \quad x / d=50\right)$

\section{5. 結論}

乱流の速度勾配テンソルの全9成分を実験的に直接測定す るために 8 線式プローブを提案し，実際に作成した. ch.5〜8 は I 型プローブとして機能することを利用して, 円柱後流に おいて $x$ 方向の乱流を調查し，過去の文献と比較しても同様 の傾向を示していることが分かった．ch.1〜4 を利用した他 方向成分については現在分析中である.

\section{引用文献}

(1) Mandelbrot,B., Fractal Geometry of Nature, WH Freeman (1982)

(2) Hurst,D. and Vassilicos,J.C., "Scalings and decay of fractal-generated turbulence", Phys. Fluids 19035103 (2007)

(3) Seoud,R.E. and Vassilicos,J.C. "Dissipation and decay of fractal-generated turbulence", Phys. Fluids 19105108 (2007)

(4) Vukoslavčević, P. and Wallace, J.M., "A Twelve-sensor Hot Wire Probe to Measure the Velocity and Vorticity Vectors in Turbulent Flow," Meas. Sci. Tech. 10 pp. 1451-1461. (1996)

(5) A. Honkan and Y. Andreopoulos, "Vorticity, strain-rate and dissipation characteristics in the near-wall region of turbulent boundary layers," J. Fluid Mech. 350, 29 (1997).

(6) Zhou, T, Zhou, Y, Yiu, MW, Chua, L.P., 'Three-dimensional vorticity in the intermediate region of a turbulent cylinder wake', Exp. Fluids 35 pp. 459-471. (2003) 